\title{
Campus Crime Reporting Under the Clery Act
}

\author{
Rachel Holder
}

$\mathbf{T}$ he Jeanne Clery Disclosure of Campus Security Policy and Campus Crime Statistics Act mandates that institutions of higher education report crimes statistics to the public and the Department of Education (DOE) in order to receive federal financial aid. This requirement led to a proliferation of data that was initially difficult to access or incorrectly reported. Recent efforts by the DOE and institutions of higher education to make this information available to the public led to access through government and university websites.

\section{Background}

Multiple high-profile incidents of violent crimes on college campuses brought America's attention to the issue of crime rates at institutions of higher education. ${ }^{1}$ The 1986 murder of Jeanne Clery in her on-campus dormitory was one of these violent events that brought the issue to the attention of the general public. ${ }^{2}$ Investigations led to the discovery that Lehigh University, where Clery attended, had thirty-eight violent crimes on campus in the preceding three years. ${ }^{3}$ Clery's parents began advocating for laws that forced universities to disclose their crime rates; their work along with the parents of other victims, lawmakers, and the popular support of the public, led to the introduction of multiple bills to address the reporting of violent crimes at institutions of higher education. ${ }^{4}$

The Congress found that "out of 8,000 postsecondary institutions participating in Federal student aid programs, only 352 colleges and universities voluntarily provide crime statistics to the Uniform Crime Report of the Federal Bureau of Investigation." Crimes committed on college campuses were included in local and state crime data, which made separating crime rates of college campuses from those of the larger community impossible. $^{6}$ This was one of the many issues that Congress addressed in the version of the bill that passed.

Congress passed the Student Right-To-Know and Campus Security Act, Pub. L. 101-542, on November 8, 1990. ${ }^{7}$ Title
II of this law, the Campus Security Act, amended the Higher Education Act of 1965 (HEA) Title IV by requiring all institutions that participate in financial assistance programs under this title to report crime statistics. ${ }^{8}$ This law has been amended on numerous occasions to add provisions on reporting, campus crime policies, or to alter the requirements for university emergency response and notification of crimes. ${ }^{9}$ One of the most significant changes came from the Higher Education Amendments of 1998 , which renamed the law after Jeanne Clery. ${ }^{10}$ This law increased the reporting requirements by adding more crimes that must be reported, increased the geographic area to include residence halls and other university owned facilities, and increased the availability of reports. ${ }^{11}$ The Higher Education Opportunity Act of 2008 added emergency response criteria and requirements for reporting hate crimes. ${ }^{12}$

In 2013, the reauthorization of the Violence Against Women Act included additional provisions for reporting crimes against women including domestic violence, stalking, and hate crimes related to gender identity. ${ }^{13}$ This law also requires institutions to add a statement of policies designed to prevent violence against women and information about available victim services. ${ }^{14}$

\section{Requirements and How Institutions Comply} Regulations related to the application of the Clery Act are located in Title 34 of the Code of Federal Regulations 668. ${ }^{15}$ However, many institutions needed more guidance to understand the terminology of the law and remove ambiguity in the DOE's expectations of universities. The General Accounting Office issued the report in 1997, Campus Crime: Difficulties Meeting Federal Reporting Requirements, that found the DOE was slow to enforce the Student Right-To-Know and Campus Security Act; many institutions (twenty-three of the twenty-five examined) did not properly report campus crime statistics. ${ }^{16}$ Universities omitted crimes reported to campus officials instead 
of law enforcement, and reported crimes in the wrong categories. ${ }^{17}$ The DOE included guidance on reporting Clery crimes in the federal student handbook and in notices sent to universities; however, these were not comprehensive. ${ }^{18}$ For example, the guidance available did not include information on reporting hate crimes, so many universities omitted hate crime information from their reports. ${ }^{19}$ Other issues were caused by institutions relying on incomplete information like arrest reports for their data, and 60 percent of reports incorrectly categorized sexrelated offenses. ${ }^{20}$ The DOE created the Handbook for Campus Safety and Security to clear up the confusion and educate universities on the Clery Act and its requirements. The first handbook was published in 2005 and has been updated to include changes to the law with the most recent version, published in 2016. The latest Handbook lists each requirement with a citation to the relevant portion of the Code of Federal Regulations; it then explains the department's interpretation of the law in a "readable manner." ${ }^{21}$ The Handbook provides a guide to determining whether an institution is accountable to Clery requirements, determining Clery geography, definitions for crime statistics reporting, how to collect statistics, explanation of the daily crime log, emergency notification requirements, and the required content of annual reports. ${ }^{22}$

The Clery Act applies to all institutions that administer federal assistance programs such as Pell Grants, Federal Perkins Loans, and the Federal Work-Study Program. ${ }^{23}$ Only distance education and foreign institutions are exempt; however, campuses of US institutions located abroad are not exempt. ${ }^{24}$ The act requires that universities publish annual reports on campus security and fire safety by October 1 of each year and include crime statistics for the last three years, campus programs and policies on crime and securing the campus, and campus programs to prevent crimes. ${ }^{25}$ The fire report must include reporting of the fire log, fire safety system for every on-campus building, and data on every reported fire and fire drill in the previous year. ${ }^{26}$ The Clery Act requires that institutions mail this publication to current students and employees, and make it available to prospective students. ${ }^{27}$ Institutions meet this requirement through mail, campus mail, or email. ${ }^{28}$ Every institution must keep crime statistics from the previous eight years that occurred on-campus, in on-campus housing, in non-campus buildings, and on public property. ${ }^{29}$ Figure 1 is an example from the Handbook that demonstrates the DOE's interpretation of the limits of Clery reporting geography. ${ }^{30}$

In addition to crime reporting, the Clery Act makes institutions of higher education responsible for maintaining a publicly available daily crime log and notifying students in a timely manner of safety threats. ${ }^{31}$ Technology has made these

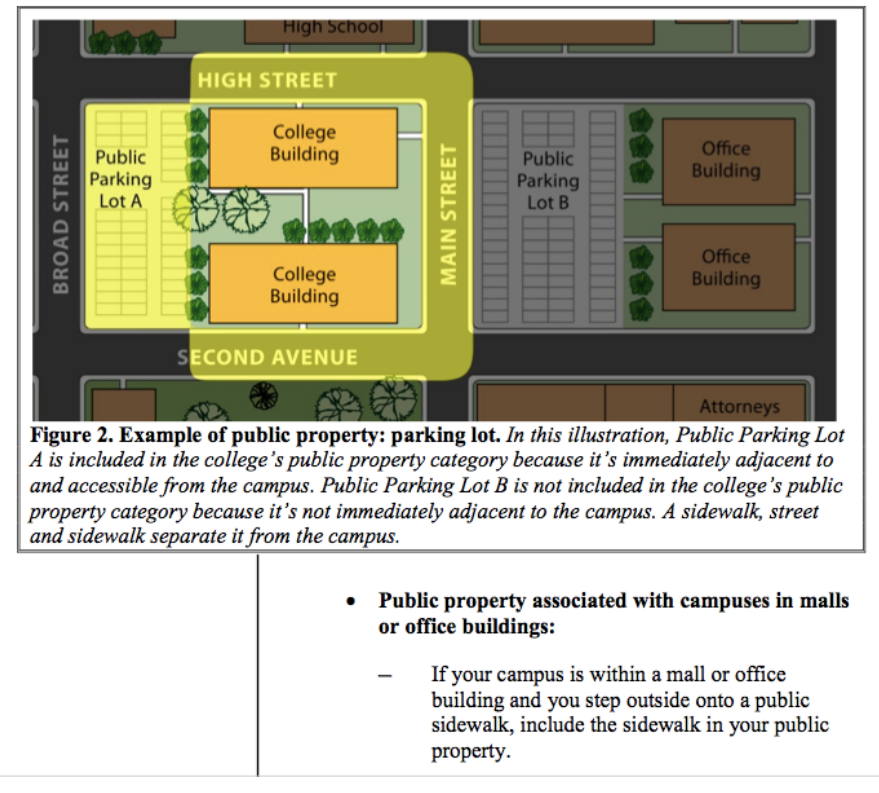

Figure 1. DOE's interpretation of the limits of Clery reporting geography, www2.ed.gov/admins/lead/safety/handbook.pdf.

requirements easier to fulfill as many institutions provide information on their websites and use Emergency Management Systems to notify students of crime via phone, SMS, and email. ${ }^{32}$

\section{Clery Act Noncompliance}

While the DOE is working to educate institutions on the requirements of Clery Act compliance through its handbook, the DOE has found institutions in violation of the law. The DOE's Federal Student Aid office conducts a review of institutions that come to their attention, either internally or through a complaint filed with them. ${ }^{33}$ In 2006, a representative of the DOE testified to Congress that between 1994 and 2006 they had conducted 4,623 program reviews and identified 252 violations of the Clery Act. ${ }^{34}$ The DOE has the ability to fine institutions for violations; however, they only fined three between 1994 and 2006. The main reason for this leniency was the lack of information available to institutions prior to the creation of the Handbook, so the DOE decided to work with noncompliant colleges to correct problems rather than punish them. ${ }^{35}$

Once an institution comes to their attention, the DOE issues a request for information from the school with details of the complaint against them. ${ }^{36}$ The school provides their response to the complaint and provides the DOE with documentation of how they comply with the Clery Act. ${ }^{37}$ The DOE reviews the institution and provides a final decision; the documentation of each of those steps is available to the public through the Federal Student Aid website (https://studentaid.ed.gov/sa/about/datacenter/school/clery-act-reports). On this website, the public can access full-text documents of complaints against an institution, 
Federal Student Aid $\mid \begin{aligned} & \text { Proud SPONSOR of } \\ & \text { the AMERICAN MIND }\end{aligned}$

An OFFICE of the U.S. DEPARTMENT of EDUCATION

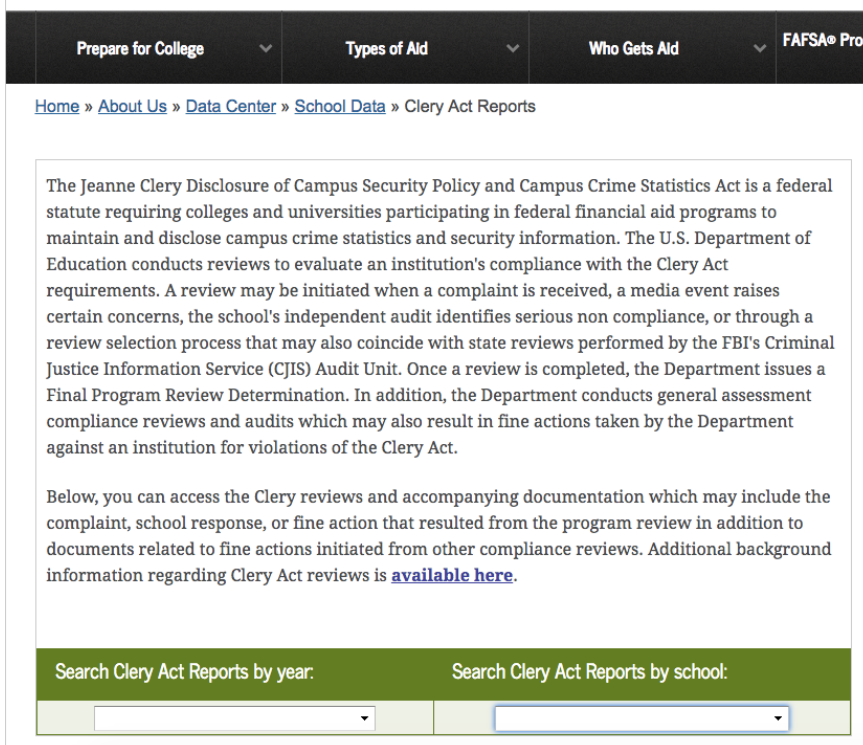

Figure 2. Database of Clery Act Reports, https://studentaid.ed.gov/sa /about/data-center/school/clery-act-reports.

DOE requests for information, schools' responses to complaints, and the DOE's determination of whether the institution complied with the law. If the institution violated the law, a description of what the violations were, and the total fine for noncompliance is stated in the fine letter or settlement with the university. These documents are accessible by year, going back to 1997 , or by school, as seen in figure 2 .

Since the 2006 hearing, the DOE found more institutions in violation of the Clery Act and levied fines against them. The DOE may fine an institution up to $\$ 27,500$ per violation, but some institutions are fined less. ${ }^{38}$ In 2016, the DOE issued its highest fine to date of $\$ 2,397,500$ for multiple violations, including failure to issue emergency notifications and improperly classifying crimes or omitting crimes from the campus crime report. ${ }^{39}$

\section{Data Access: Campus Safety and Security}

Federal attempts to share data with the public culminated in the creation of the Campus Safety and Security database Data Analysis Cutting Tool (https://ope.ed.gov/campussafety/\#/), which was launched in May 2016 by the DOE's Office of Postsecondary Education. ${ }^{40}$ The website provides access to complete datasets for crimes reported by university officials going back to 2005. The early data, 2005-12, is available to download in Excel, SAS, or SPSS files. Reports from the last three years are available for download or for users to manipulate through the Data Analysis Cutting Tools. The four tools allow users to

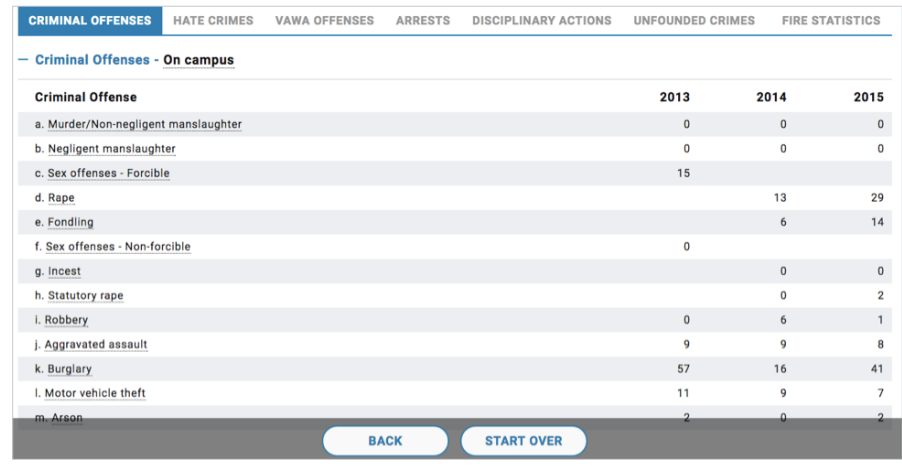

Figure 3. Three-year comparison of crime rates, https://ope.ed.gov /campussafety/\#/institution/search

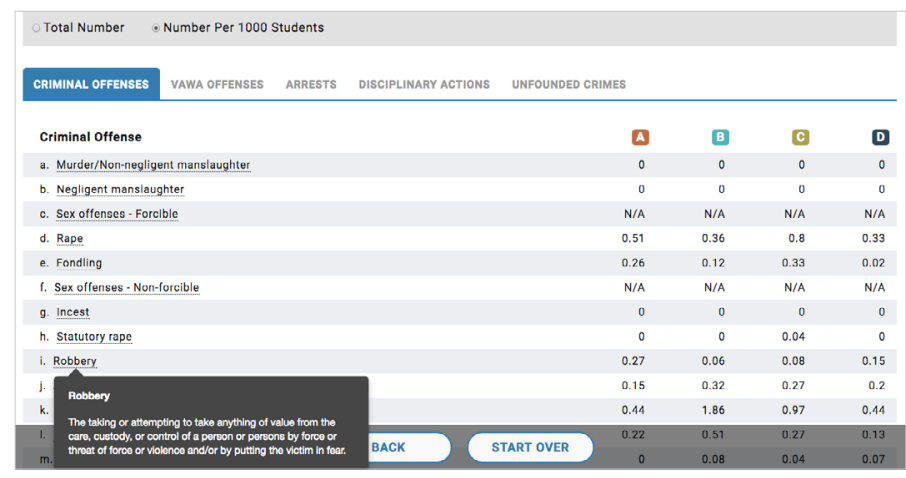

Figure 4. Comparison of crime rates at four similarly sized schools, https://ope.ed.gov/campussafety/\#/compare/details.

select a portion of the dataset for download, find data for one school, compare multiple schools, or generate national trend data. Every page of the data tool is accompanied by a bar at the top that links users to a dictionary of terminology used in Clery reporting, a user's guide, and contact information for users seeking additional help.

A user starts each search by identifying the schools sought after, and the website provides multiple points of entry. The user can start by searching for a specific university by name or the tool helps them identify the school of interest by providing criteria such as locations by state or country, size of the institution by number of students enrolled, whether it is public or private, and the subjects taught. From there, the user selects a university and views their results. The process is user-friendly and provides helpful options like saving favorite institutions.

When accessing data for only one school, the database provides information about that school such as the contact information for the university's designated safety officer, fire officer, and Title IX coordinator. This provides easy access to the appropriate people if the user has a question specific to that institution. As seen in figure 3, there is a three-year comparison of crime rates from the most recent reported years, currently 2013-15, sorted by location-on-campus, on-campus housing facilities, noncampus, and public property. There are tabs at the 


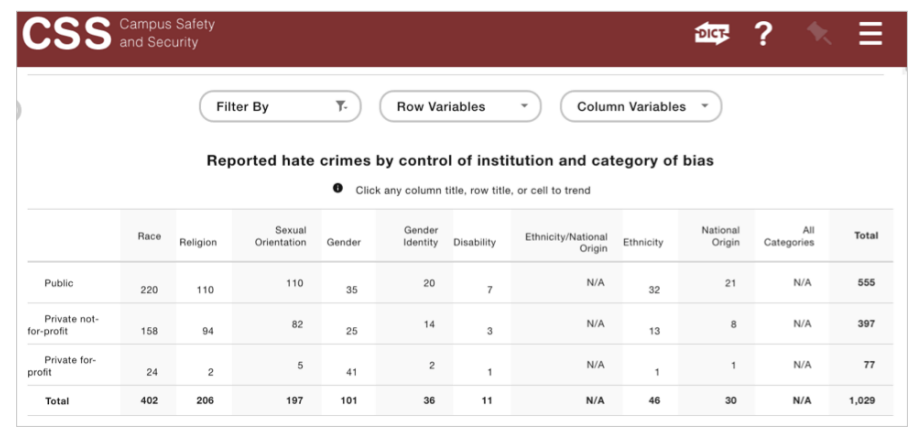

Figure 5. Custom report showing hate crimes, https://ope.ed.gov/ campussafety/Trend/public/\#/answer/2/201/table/?row=-1\&column=-1.

top to view each type of crime. This tool would be particularly useful for parents and students, since they can view the number of crimes on campus and whether the numbers are trending up or down.

The Compare Data for Multiple Schools tool provides parents and students an easy to use means of evaluating institutions of higher education. The search function for identifying universities of interest is the same as above; however, the user can select up to four universities for comparison. Figure 4 shows the campus crime rates for four similarly sized schools side by side for comparison. This data is broken down by type of crime, but offers the user the ability to switch the data to the total number of crimes or the crime rate. The crime is the number of crimes per thousand students at the university based on enrollment. ${ }^{41}$ This function enables users to easily determine if the larger university has a higher rate of crime, or just a higher total number of crimes due to a larger student population.

Users can click on any underlined term on the Campus Safety and Security data tool to access its definition without navigating to the dictionary. This feature provides transparency in how crimes are reported so that users can determine what crimes are included in each field as they look at the data.

The Generate Trend Data tool enables users to generate a chart or table based on criteria they select. The tool starts by offering a selection of the type of crimes of interest, which refers the user to questions related to that choice. For example, selecting hate crimes generates the question, "How many hate crimes were reported?" The user selects a question to move on to the next page, where the question is answered. Here the website offers many filters and variables to adapt the data to the user's needs. Users can filter the dataset by a facet, such as university size, and then create a chart or table by selecting variables of interest to them. In figure 5, hate crimes is the subject and the chart was generated by selecting the row variable control of the institution-public or private, then the column variable type of bias. This tool could be useful to parents, however, it

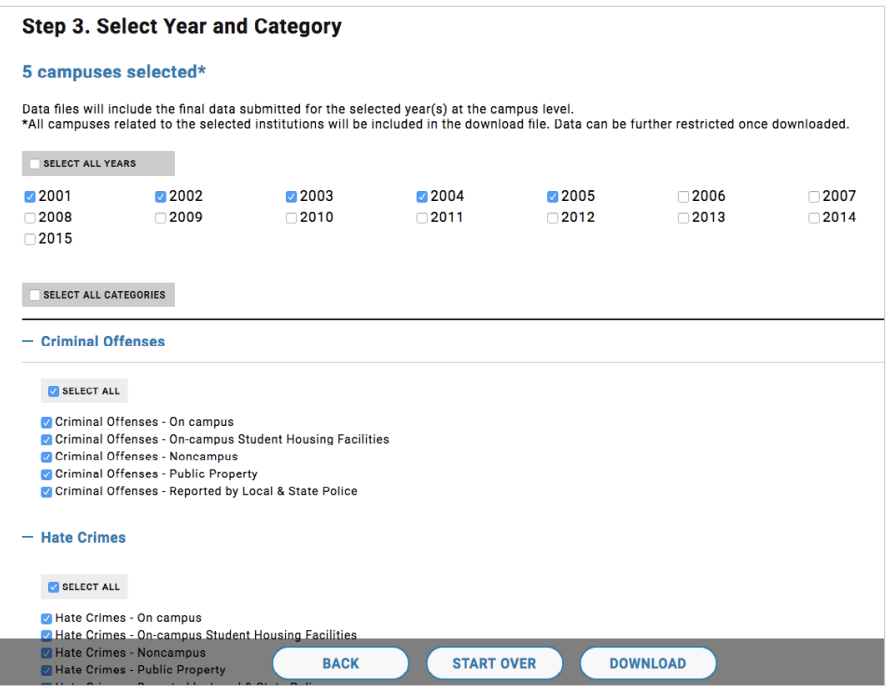

Figure 6. Custom Data Tool, ope.ed.gov/campussafety/\#/customdata/ dataselected.

holds significant value to researchers by providing a means of sorting the vast amount of data produced through Clery Act reporting. Unfortunately, this is the least user-friendly of the four data cutting tools. The first two tools lead the user through a step-by-step guided search of the data, but the trend data tool requires user exploration or use of the guide.

The final option is the Download Custom Data tool that enables users to reduce the amount of data that they download to only the most relevant information. As seen in figure 6, the options include selecting one or many institutions by enrollment, name, sector (public or private), programs offered, and location. After selecting the institutions, the user determines the years and types of criminal activity of interest. Some data available here dates back to 2001. Once a user selects the relevant topics and years, a customized dataset is generated for download. This tool would be most useful to researchers, since other tools on the website provide easier access to information sought by students and parents.

The Campus Safety and Security website provides access to data for all Title IV institutions in one convenient location. The tools available here enable anyone interested in crimes on campus to find information that suits their needs and presents it in an easy to understand manner. While some of the tools are more user-friendly than others, the tools geared towards the widest audience, multiple institution comparison and one institution's data, are also the most intuitive resources to use. The two resources geared towards the needs of researchers are less intuitive but are explained in the user guide or can be worked through with some trial and error. ${ }^{42}$ 


\section{Conclusion}

The goal of the Clery's and lawmakers when they advocated for campus crime reporting was for families to use this data to make decisions on where their children attend school. ${ }^{43}$ Since its passage in 1990, lawmakers have continued adapting it to the needs of the American people. The DOE continues to improve its publications that guide institutions of higher education through meeting legal requirements of the act, and institutions utilize current technology to meet these reporting requirements. Individual universities provide their crime statistics in reports available to potential students; however, there were issues of access for ease of comparison. The DOE's launch of the Campus Safety and Security Data Cutting Tool improved access to the data collected by providing it all in one location. The downloadable datasets are useful for researchers, but the data cutting tools provide access to everyone by enabling them to easily sort through information to find universities of interest. These tools enable the Clery Act data to serve its intended purpose of informing the parents, students, and employees of the crime rates on campuses across the country.

Rachel Holder (rmholder@indiana.edu), MLS Candidate 2018, Indiana University Bloomington.

\section{References}

1. US Congress, House of Representatives, Subcommittee on Postsecondary Education of the Committee on Education and Labor, Hearing on H.R. 3344, The Crime Awareness And Campus Security Act of 1989, 101st Cong., 2nd sess., 1990: 6-7.

2. Ibid., 60 .

3. Ibid., $60-61$

4. Ibid.

5. Student Right-To-Know and Campus Security Act. P.L. 101-542.

6. Ibid., 2384.

7. Ibid., 2383-85.

8. US Library of Congress, Congressional Research Service, History of the Clery Act: Fact Sheet, by Gail McCallion, R43759 (2014).

9. Ibid.

10. Ibid.

11. Ibid.

12. Ibid.

13. Ibid.
14. Ibid.

15. US Department of Education, The Handbook for Campus Safety and Security Reporting (Washington, DC: US Dept. of Education, 2016), www2.ed.gov/admins/lead/ safety/handbook.pdf.

16. US General Accounting Office, "Campus Crime: Difficulties Meeting Federal Reporting Requirements. Report to Congressional Requesters," March 1997, https://eric. ed.gov/?id=ED405785.

17. Ibid.

18. US Congress, Senate, Committee on the Judiciary, Campus Crime: Compliance and Enforcement Under the Clery Act, 109th Cong., 2nd sess., 2006: 9-10.

19. Ibid., 12.

20. Ibid.

21. US Department of Education, The Handbook for Campus Safety and Security Reporting, 1-4.

22. Ibid., iii-v.

23. Ibid., 1-2-1-4.

24. Ibid., 1-2-1-3.

25. Ibid., 9-1, 14-1.

26. Ibid., 1-8.

27. Ibid., 9-7.

28. Ibid., 9-8.

29. Ibid., 2-1.

30. Ibid., 2-14.

31. Higher Education Amendments of 1998, Pub. L. 105-325; The Handbook for Campus Safety and Security Reporting, 6-1-6-17.

32. Han, Wencui et al., "Campus Emergency Notification Systems: An Examination Of Factors Affecting Compliance With Alerts," MIS Quarterly 39, no. 4 (2015): 910. Retreived from Academic Search Premier, EBSCOhost.

33. White House Task Force to Protect Students From Sexual Assault, "Not Alone: The First Report of the White House Task Force to Protect Students From Sexual Assault," April 2014, https://obamawhitehouse.archives. gov/sites/default/files/docs/report_0.pdf, 17.

34. US Congress, Senate, Committee on the Judiciary, Campus Crime: Compliance and Enforcement Under the Clery Act, 109th Cong., 2nd sess., 2006: 5.

35. Ibid., 7.

36. "Clery Act Reports," Federal Student Aid, https://studentaid.ed.gov/sa/about/data-center/school/clery-act-reports.

37. Ibid.

38. US Department of Education, Federal Student Aid/ Enforcement Unit, Administrative Actions and Appeals Service Group, Pennsylvania State Fine Letter (2016), 
https://studentaid.ed.gov/sa/sites/default/files/fsawg /datacenter/cleryact/pennstate/PennStateFineLetter.pdf.

39. Ibid.

40. White House Task Force to Protect Students From Sexual Assault, "The Second Report of the White House Task Force to Protect Students From Sexual Assault," January 5, 2017, https://www.whitehouse.gov/sites/whitehouse.gov /files/images/Documents/1.4.17.VAW\%20Event.TF\%20 Report.PDF, 13.

41. US Department of Education, Office of Postsecondary Education (OPE), Campus Safety and Security Data Analysis Cutting Tool User Guide, (May 2016): 17, https://ope.ed.gov
/campussafety/public/html/help/2017_CSS_Data_Analy sis_Cutting_Tool_User_Guide_May2017.pdf.

42. Ibid., 21-24.

43. US Congress, House of Representatives, Subcommittee on Postsecondary Education of the Committee on Education and Labor, Hearing on H.R. 3344, The Crime Awareness And Campus Security Act of 1989, 101st Cong., 2nd sess., 1990. 